Article received on 14th September 2011

Article accepted on 27th February 2012

UDC: $781.01 ; 78.01$

\title{
Valentina Radoman*
}

University of Novi Sad

Academy of Arts - Department of Music

Section for Musicology and Ethnomusicology

\section{ON COMPARATIVE RESEARCH IN MUSICOLOGY: PERIPHERAL VS. CENTRAL EUROPEAN MUSICAL CULTURE AND THE MUSICOLOGICAL COMPARATIVE APPROACH IN THE 20 ${ }^{\text {TH }}$ CENTURY}

\begin{abstract}
The paper considers some of the key issues referring to the comparative research in musicology. Contrary to the science of literature, in which comparative studies have been autonomous for a long time, such is not the case in musicology. So far, musicological comparative research has not established itself as a field with distinctly defined aims, roads and development methods, nor has it been provided with adequate terminology. It may be claimed that comparative studies have been omitted from musicological research because of an idea prevailing in the second half of the $19^{\text {th }}$ century and later on, during the first half of the $20^{\text {th }}$ century, based on the fact that musical art itself was specific - special in comparison with other arts and autonomous from an extra-artistic context. This is why the comparative approach in musical art may have often been understood as a comparison of exclusive - to say it in Hanslick's words - tonally moving forms (or the art of tones) which does not and should not have any other purpose except the comparison of one tonally moving form with another one. In contrast to such a conception, this paper considers the role of political-ideological incentives to the emergence and development of comparative research. It includes the reference points of a comparative musicological narrative, namely those types of musicological comparisons analyzing the works of composers belonging to differently located European musical cultures - peripheral and central ones. In view of the fact that in the $20^{\text {th }}$ century such comparisons were mostly performed
\end{abstract}

\footnotetext{
* Author contact information vradoman@yahoo.com
} 
through a stylistic analysis (perceived as a formal analysis) of works of art, special attention has been devoted to the political-ideological instrumentalization of such analysis. The paper also puts forward the most important questions to which musicological comparative science should provide clear answers in the $21^{\text {st }}$ century.

Key words: central musical cultures, formal analysis, modernization, musicological comparative approach, peripheral European musical cultures, stylistic analysis.

Апстракт: У овом раду су размотрена нека од кључних питања која се односе на област компаративних истраживања у музикологији. За разлику од науке о књижевности у којој поредбене студије одавно поседују аутономност, у музикологији то није случај. Музиколошка компаративна истраживања нису до сада чинила област са јасном дефиницијом својих циљева, путева и начина развоја, нити су била опскрбљена одговарајућом терминологијом. Може се тврдити да је проблем компаратистике изостављан из музиколошких истраживања због идеје која је доминирала током друге половине 19. века и касније, током прве половине 20. века, о томе да је сама музичка уметност специфична - посебна у односу на друге уметности и аутономна у односу на вануметнички контекст. Због тога је могуће да је компаративни приступ у музичкој уметности често схватан као поређење ексклузивних - Хансликовим изразом речено - тонских форми (или уметности тонова) које и нема нити треба да има икакву другу сврху до поређења једне тонске форме с другом тонском формом. У овом раду је, насупрот таквом схватању, размотрена улога политичко-идеолошких подстицаја у настанку и развоју компаративних истраживања. Наведене су упоришне тачке компаративног музиколошког наратива, и то оне врсте музиколошких поређења у којима су анализирана дела композитора који припадају различито позиционираним европским музичким културама - периферним и централним. С обзиром на чињеницу да су таква поређења током 20. века најчешће спровођена путем стилске анализе (схваћене као формалне анализе) уметничких дела - посебна пажња је посвећена проблему политичко-идеолошке инструментализације такве врсте анализе. Такође су назначена најважнија питања на која би музиколошка компаратистика у 21. веку морала да пружи јасне одговоре.

Кључне речи: централне музичке културе, формална анализа, модернизација, музиколошки компаративни приступ, периферне европске музичке културе, стилска анализа.

\section{Introduction}

Unlike the literary studies in which comparative (literary) studies long ago won their autonomy and contemplated the issues of their origin during the process, declared the date of their termination, ${ }^{1}$ and their new beginnings af-

1 Here, it is sufficient to quote only one of the characteristic statements about the end of comparative literature: "Today, comparative literature in one sense is dead". Susan Bassnett, Com- 
terwards, at the same time dealing with the matters of their aim, purpose, methodology and terminology, such is not the case with musicology. Musicological comparative research is not an autonomous field within musicology, nor is it based in theory. True enough, the science of music also uses the term vergleichende Musikwissenschaft, its equivalent in English being Comparative Musicology and La musicologie comparée in French, which explains the Serbian term - komparativna muzikologija. However, although it evokes associations to numerous comparative research studies practicable in musicology, until recently the above term was used to designate a musical science which not only failed to treat the comparative method as the sole research method, but did not even consider it as the primary one. After this musical science was given a different name - ethnomusicology - in the second half of the $20^{\text {th }}$ century, the term comparative musical science or comparative musicology lost its function. The meaning of the term was never modified and never used afterwards as a collective name for all musicological research studies based on a vaguely defined approach (to a particular subject) known as the comparative approach. ${ }^{2}$ The word vaguely is used because it is completely unclear whether this research approach in musicology obliges one to anything else except to any kind of comparison.

What can be compared in the area of music? Although the answer to this question could be extensive and systematically outlined, only some general hints will be given here. The following items can be compared: a) all or some of the musical parameters of a musical piece by one author with corresponding parameters of another musical piece by the same author; b) all or some of the musical parameters of musical pieces by one author with corresponding parameters of musical pieces by another author or a group of authors, within the same musical style, period, epoch; c) all or some of the musical parameters of musical pieces by one author with corresponding parameters of musical pieces by another author or group of authors, within different musical styles, periods, epochs; d) some of the musical parameters of musical pieces (of a certain number of representatives) of a single musical style, period or epoch with the same parameters of musical pieces (of a certain number of representatives) of other

parative Literature. A Critical Introduction, Oxford, 1993, 40, 41, 47. Quoted after: Gvozden Eror, Književne studije i domen komparatistike [Literary Studies and the Domain of Comparative Studies], Beograd, Pančevo, Institut za književnost i umetnost, Mali Nemo, 2007, 9.

2 This is not about advocating the autonomy of comparative research studies in musicology, but merely an indication as to the necessity of a careful approach to comparisons of pieces of music with full awareness of the reasons and purpose of comparison, as well as of the consequences of the obtained scientific results. 
musical styles, periods or epochs; e) some of the musical parameters of musical pieces by one or more authors with corresponding, analogous parameters of authors belonging to other arts within the same artistic style, period or epoch; f) some of the musical parameters of musical pieces by one or more authors with corresponding, analogous parameters of authors belonging to other arts within different artistic styles, periods or epochs; g) all or some of the musical parameters of a musical piece by one author viewed from a perspective of a non-musical context with corresponding parameters of another musical piece by the same author determined by a different non-musical context, etc.

There is no doubt that music offers tremendous possibilities for various types of comparison. Consequently, it is rather unusual that so far musicology has failed to consider in detail the criteria for selection of musical pieces to be compared, the method or purpose of comparison, etc. It is possible that musicology, still regarded as a young science, has not had enough time so far to deal with the problems of comparative studies and all pertaining issues related to comparative research, which is the reason why the comparative approach has often been either regarded as an implied constituent factor of the history of music, history of musical styles or history of musical shapes, i.e. the science of musical shapes, or taken over from other sciences (first of all from comparative literary studies), without the careful adaptation of all aspects of this approach or methods to the features of musical art and science. We can say that this was mainly done because of the idea, predominant in the second half of the $19^{\text {th }}$ century and later, during the first half of the $20^{\text {th }}$ century, that musical art itself is specific - special - as opposed to other arts and autonomous from an extra-artistic context. This is why the comparative approach may have often been understood as a comparison of exclusive - to use Hanslick's expression - tonally moving forms (or the art of tones), ${ }^{3}$ which does not and should not have any other purpose except the comparison of one tonally moving form with another one. Accordingly, in all such (past or present) cases of acceptance of the formalistic idea about the specific and autonomous nature of music and advocacy of the 'comparison for comparison's sake' concept, René Étiemble's witty and, above all, wise saying 'comparaison n'est pas raison' ['comparison is not a reason'] unfortunately loses its importance. This specific nature of music is usually linked to the fact that, as Hanslick's example also proves it, throughout its entire history music has most rarely of all other arts been experienced and considered as some kind of 'language' or a sequence of signs capable of articulating, reflecting, evoking, representing or depicting something that does not

3 Eduard Hanslick, Vom musikalisch-Schönen; Ein Beitrag zur Revision der Ästhetik der Tonkunst, Leipzig, Breitkopf\&Hartel, $1910^{11}$. 
belong only to the music medium. Quite an important quality has therefore been attributed to certain examples of art music - 'universality' (that can be linked to the quality of 'supranationality' in a world divided into nations), which literature, for example, split into numerous national literatures (literatures in the languages of different nations) could not boast of. For this reason, Johann Wolfgang von Goethe's concept of studying all literatures of the world, i.e. 'world literature', is gladly accepted, although without much success. ${ }^{4}$ As far as socalled art music is concerned, its 'universality' in musicology was never questioned for a long time. It was not even done in the light of the fact that it became clear over time that this so-called universality was actually reduced to the rules established in some musical pieces written mostly by German composers, or in a certain number of canonical works by Western European authors, nor was it done in consideration of the fact or illusion, accepted during the $19^{\text {th }}$ century, about the existence of 'national music idioms' - as an alternative to the universality of music. ${ }^{5}$ The question about whether music should be studied as a universal code of rules pertaining to the composing technique and which has been established in art music over time, i.e. as an undisputed set of music trade laws in which certain characteristics of the Volksgeist (national spirit) - as Herder and Hegel would designate it - can very well be fitted, or as a set of different music idioms disturbing or redefining or not fitting into this "universal" code of composing rules, is a question that should be considered in musicological com-

4 Among other scientists, Dionyz Durisin also states this, when he says: “...In the history of literary thought, we meet an entire range of various conceptions of world literature. They range between two extreme positions: from an extremely simplified sum of national literatures and analogous literary units, to a surreal and inaccessible fiction which is almost lost in literary infinity. Both extremes bear witness to the fact that world literature is not always approached through a scientific and literary method and that only empirical aspects are often applied. The conception of a mechanical sum of national literatures and similar literary-historical complexes shows the incapacity to interpret world literature as a whole and as a system with mutually conditioning and interconnected components. On the other hand, the conception of an overly abstract fiction results from the surreal and, in its essence, a priori interpretation of the inter-literary process.” Dionýz Ďurišin, Čo je svetová literatúra? Vydavatel'stvo Obzor, Bratislava, 1992. (Dioniz Đurišin, Šta je svetska književnost? [What Is the World Literature], trans. Miroslav Dudok, Sremski Karlovci, Novi Sad, Izdavačka knjižarnica Zorana Stojanovića, 1997, 13.)

5 The idea presented by German researchers, such as Willi Apel, that 'musical nationalisms' existed ever since the $19^{\text {th }}$ century and that nevertheless German music was not 'national', which also applied to the French and Italian music, has its advocates even today. For critics on this concept see Richard Taruskin, 'Nationalism', The Revised Grove Dictionary of Music and Musicians, ed. Stanley Sadie and John Tyrrell, XVII, Basingstoke, McMillan, 2001, 687706. 
parative research studies before any other ones - which is exactly why this text only includes consideration of a single aspect of the question. This antagonism or dialectics between the universal and the individual/local is one of the greatest stumbling blocks in comparative studies of musical pieces by authors coming from different musical cultures, particularly if one of the authors comes from - to put it in terms of the postcolonial theory - a central or dominant musical culture, while the other one comes from a peripheral or marginal culture. ${ }^{6}$ This problem can initially be also viewed from the Eurocentric perspective - as a relation between specific European peripheral and central cultures. ${ }^{7}$

\section{Peripheral vs. Central European Musical Cultures and Comparative Research Studies}

Before we go on to discuss individual examples of musicological comparisons of compositions by the authors belonging to differently located musical cultures - peripheral or central, we should recall the fact that in various arts, until the second half of the $20^{\text {th }}$ century such and similar comparisons in Europe (and the United States of America as a place offering a home to - among others - the European diaspora) were mostly performed through a stylistic analysis - perceived as a formal analysis for which the theoretical foundations were laid in the $16^{\text {th }}$ century (in visual arts), and the $17^{\text {th }}$ century (in music), while in literature it was mentioned ever since ancient times. ${ }^{8}$ Based on 'grouping of like

6 Having in mind that there are numerous debates on the meaning of the word 'culture', this term will here be used in the traditional sense, often in the syntagm 'musical culture', as a synonym for 'art', in this case 'music art' meaning music art in a single society, national community, country, etc.

7 Instead of the terms 'central' and 'peripheral' culture, the Yugoslav comparative literature used designations such as 'velika, zakonodavna' ['major, legislative'] and 'mala, nezakonodavna' ['minor, non-legislative'] literature (culture). See Zoran Konstantinović, Komparativno viđenje srpske književnosti [Comparative Perception of the Serbian Literature], Novi Sad, Svetovi, 1993, 6.

8 Giorgio Vasari's book Lives of the Most Eminent Painters, Sculptures and Architects from 1568 is regarded as a work that inaugurated art history as a modern discipline and one of the first works where the author uses the term "style" within an art historical analysis. Cf.: Jaś Elsner, 'Style', in: Critical Terms for Art History, ed. Robert. S. Nelson and Richard Shiff, Chicago, University of Chicago Press, 2003. In music, the term 'style' was introduced around 1600. Among the first ones to use it were P. Pontio (Ragionamento di musica, 1588) to designate a set of expressive means within specific musical forms (motet style, madrigal style, mass style, etc.) and L. Zacconi (Prattica di musica, II, 1622) to designate a set of expressive means specific to the musical works of a composer. Later on this term gained many additional meanings. In the $19^{\text {th }}$ century, the term 'style' was customarily used to designate a whole set of 
with like and the disjunction of unlikes, on the basis of morphological or formal analysis', stylistic analysis enjoyed the status of objective examination of works of art for centuries until finally, at the end of the $20^{\text {th }}$ century, it was observed that stylistic analysis was based on the personal judgment of a researcher, after all. Given the fact emphasized by art historian Jaś Elsner that subjectivity does not in any way exclude convincing argumentation, the newly discovered quality of stylistic (in the sense of formal) analysis did not stir considerable controversy until certain art theoreticians pointed out that morphological or formal analysis, treated as stylistic analysis, was often supplemented with an interpretation presented in a special political-ideological tone. ${ }^{9}$ Hence, for example, ' ... the racist German art history of the pre-war years used style to determine ethnic origin in an overtly ideological program of reshaping the canon according to Aryan and Nordic principles. It attributed the demise of Classical art forms in Late Antiquity, for example, to the dreadful, indeed specifically the Semitic, influence of the Orient (...) when "Hellas was suffocated in the embrace of the Orient" / Strzygovski, 1905, 23/'. ${ }^{10}$ After giving plenty of similar examples showing the political-ideological abuse of stylistic observations, Elsner notes that stylistic analysis and even the term 'style' were carefully omitted from scientific papers in the seventies and eighties. Still, the end of the $20^{\text {th }}$ century and the beginning of the next one were marked by the return or echoes of the term in question, while '...the new art history - so much more methodologically and theoreti-

all the characteristics of previous musical periods. Thus, Guido Adler (Der Stil in der Musik, I, Leipzig, 1911) studied the entire history of music as a history of musical styles. Musicology took over the names of specific style periods from the history of visual arts and literature or from some other cultural-historical streams. Cf.: Josip Andreis, 'Stil' ['Style'], Muzička enciklopedija [Musical Encyclopedia], 3, Zagreb; Jugoslavenski leksikografski zavod, 1971, 458.

9 The interpretation of facts (which could also be applied to the interpretation of results obtained by formal analysis in music) served as a subject of study particularly to the scientists of the postcolonial stream, but to others as well. If we were to refer to Edward Said's opinion that meanings result from a narrative plan rather than from deductions from facts, and that facts can always be read in different ways (Edward Said, Culture and Imperialism, London, Chatto and Windus, 1993), or to Lionel Gossman's opinion that all narrations, including those supported by accurate documentation, have much more in common with fictional story-telling than researchers are usually willing to admit (Lionel Gossman, Between History and Literature, Cambridge, Harvard University Press, 1990, 286), then we could claim that both formal analysis in music (perceived as one of the sources of facts) and the interpretation of such analysis hardly ever (actually never) build a tautological relationship, and instead they create a more or less creative 'free counterpoint'. So, even a formal analysis and its interpretation build a construct of knowledge and beliefs which depends on the researcher's theoretical, ideological, political, culturological, historical, etc. position.

10 Jaś Elsner, op. cit., 103-104. 
cally grounded, so much more historicist and contextually subtle, so much more politically nuanced and socially explicit', ${ }^{11}$ returned or in some way remained faithful in certain works to the stylistic apparatus.

Even though morphological or formal analysis (perceived as stylistic analysis or the analysis of art paradigms such as avant-garde, modernism, postmodernism, etc.) never faced such resistance in musicology, particularly in the musicology of peripheral cultures, which Jaś Elsner talks about with reference to the history of visual arts, it was nevertheless exposed to new challenges over time arising from manifold areas of science and social practices - first of all from literary theory, then from the feminist movement, cultural studies, etc. during the second half of the $20^{\text {th }}$ century.

Thus, for example, stylistic analysis - in cases where a particular style was interpreted as a consistent set consisting primarily of the corresponding formal, i.e. morphological properties of a large number of musical pieces by one or more authors - had to be redefined as far back as the seventies (or even much earlier). ${ }^{12}$ At that time literary theory replaced its perception of a work of art (œuvre) as a completed, or it may as well be said a physical object, with the perception of the work as a text implying a process of creation of a meaning, i.e. a process in which a text is a product created by the active participation of the listener/reader/viewer, while at the same time inter-textual connections with the entire corpus of other texts are being developed (both the text, its author and its recipient are implied as doers of the action). ${ }^{13}$ Such perception of a work

11 Jaś Elsner says: 'For nearly the whole of the $20^{\text {th }}$ century, style art history has been the indisputable king of the discipline, but since the revolution of the seventies and eighties the king has been dead. (...) Dead though the father may be, we cannot be entirely sure how much his children are fashioned in his likeness.' Ibid, 98-99.

12 If we take into consideration the works by Viktor Shklovsky and Mikhail Bakhtin in connection with the issue at hand, then we can talk about the early decades of the $20^{\text {th }}$ century instead of the seventies.

13 Following the work of Julia Kristeva, Roland Barthes laid the foundations of literary theory about text in his essay De l'ceuvre au texte (From Work to Text, 1971). According to him, '.... a work can be seen in bookshops, catalogues, exam programmes, whereas a text is a demonstration process, it tells us something by certain rules (or against certain rules); while a work can be held in the hands, the text is contained within a language, it exists only in the movement of speech (or even better, it is a Text because it knows that it is a text): Text is not about breaking a work apart (...) Text is experienced only in production activity. Consequently, Text cannot be halted (for example, on a bookshelf); the constitutive motion of text is about going all the way through (it can pass through a work, through several works)'. Cf.: Miroslav Beker, 'Tekst/ Intertekst' ['Text/Intertext'], in: Intertekstualnost \& Intermedijalnost [Intertextuality \& Intermediality], Zagreb, Zavod za znanost o književnosti, 1988, 11. 
of art, transferred from literary theory to musicology, could not leave stylistic analysis in the original position. By taking over the concept of text/intertext, researchers were forced to focus their attention on the heterogeneity of the textual structure, ${ }^{14}$ which often, though not necessarily, suggested stylistic heterogeneity of the observed item. Stylistic heterogeneity of the observed artistic text was actually not as important as the disclosure of the very style as a heterogeneous structure. This shook the foundations of stylistic analysis which was grounded exactly on the concept of homogeneity or on the implication of (focus on) the mutual harmony of various parameters of a piece of art/music or on the connection of musical pieces within an entire opus by a single composer or within a single stylistic movement or period.

In the musicology of peripheral cultures, such as the former Yugoslav or Serbian or Croatian and other cultures of the present day, particularly in musicological papers discussing the compositions of local, national authors, the concept of inter-textuality has not aroused the interest or researchers. ${ }^{15}$ On the other hand, the comparative stylistic (mostly formal) analysis/analysis of artistic paradigms - which compared the compositions of local authors with European canonical pieces by various criteria - dominated research studies in musicology as the most important instrument in the strategy of the presentation of the peripheral nations' musical heritage throughout the $20^{\text {th }}$ century. ${ }^{16}$

This insistence on a single concept characterizing the musicology of the peripheral European cultures, which was determined not to be quite suitable, i.e. not completely reliable from a methodological point of view in (literary) theory studies of the central cultures, and not to be even politically correct according to modern art theory ('so much more nuanced politically and socially'), can be explained by a special form of 'communication' which was, it seems, inevitably, established in the musicology of the peripheral cultures with the central ones.

However, before we go on to discuss this special form of communication, we should recall the fact that the first major contributions to the constitution of comparative studies, first of all in literature, were made by Abel-François Vil-

14 In the above essay (written in 1971), Roland Barthes noted the etymology of the words text and intertext which originate from the Latin words textere and intertextere meaning weave, knit, or interweave, interlace, pointing out that each text is just a part of already existing knitwork that will go on existing in all its further modifications.

15 Any kind of perception of the intertextuality concept is implied: the one proposed by Julia Kristeva or Roland Barthes, Michel Arrivé, Laurent Jenny, Michael Riffaterre, etc.

16 Even the countries with a long and important musical tradition, such as the Czech Republic or Russia, keep re-examining the relationship between their musical heritage and the canonical pieces of Western European music. 
lemain (1790-1870) - a French writer and politician, afterwards admitted to the French Academy (L'Académie française). He was so inspired by comparative philology, or comparative research on languages, that he raised his comparative research in literature to the level of a science, naming it littérature comparée, at the Sorbonne in Paris as far back as in the 1820's. In his Lectures in French Literature, Villemain in the first place emphasized the importance and power of French culture over other European cultures. Thus, for example, Lesson 31 of the printed version of his lecture Review of $18^{\text {th }}$ Century Literature (1840) began with the words: 'Gentlemen, we have seen how imitation of the French spirit affects England and Scotland.' ${ }^{17}$

In 1852, in the principality of Serbia (the culture of the Serbian people is here given as an example of one of the peripheral European cultures), ${ }^{18}$ Matija Ban (1818-1903), a writer and politician from Dubrovnik, a member and afterwards a secretary to the Serbian Royal Academy of Science, spoke about 'compared literature' 19 while delivering his admission speech as a newly appointed professor of the Belgrade Lycée, the highest educational institution of that time in the principality of Serbia. Unlike Villemain, for whom comparative literature meant emphasizing the power of the French spirit, Matija Ban explained his perception of comparative studies as the necessity for setting up new road signs for the development of Serbian culture, which was at that time under way within the administrative (and also symbolic) setting of the Austro-Hungarian empire in one part and the Ottoman empire in the other. As an ardent follower

17 Abel-François Villlemain, Cours de littérature française - Tableau de la littérature au XVIIIe siècle, 2e édition revue, corrigée et augmentée, Paris, 1840. Cf. Gvozden Eror, op. cit. 15.

18 Although the conclusions of this study are based on an insight into the musicological texts of Serbian, Croatian, Slovenian, Romanian, Czech and Russian researchers, only the examples of musicological research in Serbia have been given here as paradigmatic. The reason is pragmatic - the author of the study comes from Serbia, and the primary target reader audience is also Serbian. Therefore, the criterion for the selection of examples of comparative research is 'practical' or 'artificial' or even 'pretentious', as it is most often the case in musicology when examples for comparison of compositions are selected. The issue of criteria according to which examples for comparison in musicology are selected ought to be addressed in a separate study.

19 Zoran Konstantinović, 'Čemu komparatistika? O nekim nedoumicama u razvojnim tokovima naše kulture' ['What is the Purpose of Comparative Studies? On Some Doubts in Development Streams of Our Culture'] (Academic admission speech held at the gala meeting of the Serbian Academy of Sciences and Arts on 30 $0^{\text {th }}$ May 1995), Glas Srpske akademije nauka i umetnosti, CCCLXXVII 1995. (Reprinted in: Polazišta; Izbor iz radova Zorana Konstantinovića, Novi Sad, Prometej 2000, 33.) 
of French culture and enthusiastic advocate of the idea of unification of the Slavic nations, Matija Ban directed his listeners to look for their role models with the French people and in the Slavic world so that they could detach themselves from the overly strong German influence in the first place. ${ }^{20}$

Both of the above cases (also) clearly show political-ideological incentives for the establishment and development of comparative studies. This undisguised, distinct political-ideological incentive, as a constituent factor of comparative research studies (in various fields), has persisted until today. As noted, this is also easily perceivable in the modes of interpretation of the works by national composers from the peripheral cultures, i.e. in 'strategies for national self-presentation' used in the musicology of peripheral European cultures.

Before anything else, like scholars from other disciplines in the humanities, the musicologists of the peripheral European cultures are encouraged or perhaps even forced to employ the strategy of emphasizing the specific qualities of their own cultural traditions. At the same time, this action means distancing themselves from the neighbouring national cultures or completely disregarding them. Selection of this strategy can be explained with the words of anthropologist Michael Herzfeld. Considering the concept of cultural differences based on the Us/Them division in the context of the images of the Balkans, i.e. considering the concept of differences between central and peripheral cultures, he noted: 'One persistent paradox runs through the majority of negative stereotypes of the self-proclaimed West: the Other is so hopelessly different, fragmented and divided inside that, in the end, all these nations appear radically similar. Who can distinguish so many diversities? It is easier to write them off as the same. ${ }^{21}$ Anthropologist Ivaylo Ditchev therefore additionally concludes that in cases of peripheral cultures, the purpose of the national features most emphasized by scientists is to 'be presented to the great western Other (central, dominant European cultures; comment by V. R.) which should pass judgment that your country is better than the rest'. ${ }^{22}$

The scope of significance this issue bears, to the extent that sometimes the efforts aimed at its resolution seem odd and irrational in scientific discourse, can

20 Cf. Ibid, 34-35. Matija Ban held his seminar for a short time in 1852. After him Aleksa Vukomanović, a newly appointed professor of the Lycée, taught 'Theory of Literacy' and 'History of Literacy of Major Nations' as of 1853. Cf. Zoran Konstantinović, Komparativno viđenje... [Comparative Perception...], 47.

21 Michael Herzfeld, Uvod [Introduction], in: Balkan kao metafora: između globalizacije $i$ fragmentacije [Balkans as a Metaphor: between Globalization and Fragmentation], Dušan I. Bjelić, Obrad Savić, eds., Belgrade, Beogradski krug, 2003, 13.

22 Ivajlo Dičev, "Eros identiteta" ["The Eros of Identity"], in: Ibidem, 278. 
be shown in an example of a comparative study being highly influential locally even today and which can be claimed to be one of the cornerstones of Serbian musicology. It is Marija Bergamo's study titled 'Elementi ekspresionističke orijentacije u srpskoj muzici do 1945. godine' ['Elements of Expressionistic Orientation in Serbian Music until 1945'] written in the seventies (printed in 1980) at the time when, among others, Serbian, Croatian and Slovenian cultures were developing within the administrative and symbolic setting of a single country Yugoslavia. ${ }^{23}$

Meticulously discussing numerous pieces by Serbian composers in which musical parameters were treated in an expressionistic way, ranging from a hint of expressionism to the consistent application of expressionistic composing procedures, in her study Marija Bergamo resorts to the above strategy of 'emphasizing specific qualities' (suitable representative samples) of a peripheral nation's culture - the Serbian culture. Implying stronger ties of Serbian music expressionism with German (and Czech) expressionism than with the local examples of this style, Marija Bergamo writes without further elaboration: 'O nekom zajedničkom tipu jugoslovenskog muzičkog ekspresionizma teško bi bilo govoriti i pored univerzalnosti izražajnih sredstava koja ga karakterišu kao pravac u užem smislu.' ['It would be difficult to talk about some common type of Yugoslav music expressionism in spite of the universality (underlined by V. R.) of the expressionistic instruments characterizing it as a style in the narrower sense.' ${ }^{24}$ The author's intention to detach Serbian culture from the local/regional context and place it closer to the central cultures is suggested quite subtly. However, the paradox of this statement has not been toned down. Because if, according to Marija Bergamo, certain Serbian composers once consistently used the composing technique that was quite close to Arnold Schoenberg's way of composing - who was mentioned as a paradigmic case of music expressionism, i.e. as a universal way of expressionistic composing - then two key questions arise. The first one is whether this statement means that Croatian and Slovenian expressionist composers did not write pieces comparable with Schoenberg's, whereas the second question refers to the comparative context

23 Marija Bergamo, Elementi ekspresionističke orijentacije u srpskoj muzici do 1945. godine [Elements of Expressionistic Orientation in Serbian Music until 1945], Belgrade, Srpska akademija nauka i umetnosti, 1980. Primarily owing to its significance and scope of research, Marija Bergamo's study has been referred to in this text as a particularly intriguing example of a special form of comparative approach. However, since comparison is one of the most often applied approaches in studies about peripheral cultures, the list of other studies or shorter papers which could have also been discussed in this text is really extensive.

24 Marija Bergamo, op. cit., 3. 
selection criteria, i.e. the criteria according to which it has been established that the expressionist pieces by Serbian composers cannot be compared (to the level reached of uniform typology) with expressionist works by Croatian or Slovenian composers, while they can be compared with German expressionist pieces.

If, however, Maria Bergamo's statement is taken in the context of the 'periphery-getting-closer-to-the-centre' strategy, characteristic of one aspect of comparative studies, it becomes clear that such a statement should be read while having in mind its significant, for comparative research immanent, political-ideological function (which in this case represses its trueness). This is the same function that induced Romanian historian Nicolae Iorga, for example, to conclude as far back as in the early $20^{\text {th }}$ century that 'Romanians were closer neighbours to Paris than to Belgrade and Sofia' ${ }^{25}$ or scientists at the other end of the world to claim that 'brazilski autori saobraćaju više sa Lisabonom, Parizom, New Yorkom i Londonom nego s Buenos Airesom, Santiagom de Chile ili Meksikom' ['Brazilian authors communicate more with Lisbon, Paris, New York and London than with Buenos Aires, Santiago de Chile or Mexico'], ${ }^{26}$ or that 'pisci u Čileu i Argentini govore španjolski, ali misle francuski' ['writers in Chile and Argentina speak Spanish, but think in French']. ${ }^{27}$

Interestingly enough - unlike comparative literature studies in which the issues of influence, imitation, borrowing, reception, etc. are examined in detail - in musicology even the word 'influence' is employed rather rarely, that being one of the most often used expressions in comparative literature research studies (at least by the mid- $20^{\text {th }}$ century). In the musicology of peripheral European cultures, particularly when referring to the composers who worked mostly in

25 Iorga, Études Roumaines, 10. Cf.: Ivajlo Dičev, "Eros identiteta" [“The Eros of Identity"], in: op. cit., 278, 284. The above issue of Romania distancing itself from the neighbouring cultures was specifically addressed by Doina Harsanyi and Nicolae Harsanyi. The authors showed how in its recent history Romania had an exaggerated need to distance itself from its orthodox and Slavic neighbours, Russia in particular, which resulted in its turning to the French culture as its major role model. Although it did not belong to the French empire, Romania behaved like a typical colony, making it quite an interesting fact if we know that the French culture reached Romania only indirectly in the $19^{\text {th }}$ and early $20^{\text {th }}$ centuries - through the big Russian landowners who cherished the French language and culture on their estates. D. Harsanyi, N. Harsanyi, 'The Discreet Charm of the Little Sister: France and Romania', in: East European Quarterly, Summer, 1994, No. 2. Cf.: Branimir Stojković, Identitet i komunikacija [Identity and Communication], Belgrade, Čigoja štampa/Fakultet političkih nauka, 2002, 16.

26 Cf.: Aleksandar Flaker, Stilske formacije [Stylistic Formations], Zagreb, Sveučilišna naklada Liber, 1986 (1976), 64.

27 Ibidem. 
the first half of the $20^{\text {th }}$ century, we frequently find information about the places where the composers of that specific peripheral culture received their education (which, in fact, already implies being influenced by the works of those distinguished European composers which had become canonical and were therefore studied or are still being studied in the educational institutions of many European countries) or which of the new works from central musical cultures the peripheral culture composers had the opportunity to hear (usually only once, without access to the score). On one hand, $20^{\text {th }}$ century musicology thus avoided facing the complex problems caused by the concept of influence. First of all, this created 'a shortcut to the centre' (which is impracticable in literature, among other things because translations from the languages of central cultures into the languages of peripheral cultures are required) and enabled the study of the creative work (only certain pieces or the entire opus) of the composers from peripheral cultures as something formed at the very 'source of universality', thus having the potential of universality itself. In this way, an endless discussion was smoothly avoided about the ironic question raised in comparative literature studies by Claudio Guillén. The question runs like this: does the discovery of an exerted influence completely change the assessment of the works of art involved? Or, in the case of an affirmative answer, is studying works of art created under a certain influence - instead of them exerting influence on other works - an act of mercy?28

If, after all, we look in musicology for the answer to Guillén's question as to why 'specific' and not 'universal' works by artists from peripheral cultures are studied (or what is the purpose of such research), the above mentioned study by Marija Bergamo will provide the answer characteristic of the researchers of peripheral cultures, particularly of those for whom stylistic, i.e. formal analysis was the only primary research apparatus during the $20^{\text {th }}$ century and the national perspective, by a combination of circumstances, was almost the only favourable choice. The answer is that there is a possibility (or researchers believe in this possibility) that 'specific' works will become 'universal' over time. Therefore, having performed a careful formal analysis of numerous examples of the 'specific' music expressionism in Serbian music, Marija Bergamo concludes that 'osnovni smisao' ['the essential point'] (of the use of expressionist elements in Serbian music until 1945; comment by V. R.) is 'pre svega u stvaranju svesti o velikim mogućnostima koje se (...) pružaju nacionalnoj kulturi u borbi za njenu međunarodnu afirmaciju' ['in developing an awareness of the great opportunities

28 Claudio Guillén, Literature as system: essays toward the theory of literary history, Princeton University Press, 1971. (Klaudio Giljen, Književnost kao sistem, trans. Tihomir Vučković, Beograd, Nolit, S. a, 43.) 
(...) offered to a national culture in its struggle for international recognition']..$^{29}$ This typically modernist thought - about the (research-proven) conquest of 'the new' as a special quality sufficient for entering the canon of universal works of art of dominant cultures - seemed a kind of Utopia in the $20^{\text {th }}$ century. Still, on the other hand, the radical redefinition, extension or destruction of the traditional canon of dominant musical cultures (the original form of which never included 'specific' works from many peripheral cultures after all) ${ }^{30}$ that went on throughout the $20^{\text {th }}$ century, did indeed offer the paradoxical possibility for this concept to be materialized in one form. The materialization of this possibility, however, no longer has any connection with stylistic innovations, or with the universality of music, but rather the contrary. The multicultural landscape of today - with its redefined relationship between the periphery and centre requires a 'radical specificity' which is able both to mildly shake and strongly confirm the homogeneity of globalized (universal) culture at the same time. ${ }^{31}$ Musicological discussion regarding the specific nature of works by composers from (former) peripheral cultures has consequently been given a new shade in the $21^{\text {st }}$ century, although it is essentially based on the same strategy of proving itself, as Ditchev said, to the great Other (dispersed across the global market in the $21^{\text {st }}$ century) which is to confirm that the culture (of the representatives) of one nation is better (more interesting, appealing, desirable on the market) than (similar) other ones.

One of the most interesting differences that can be distinguished among the self-presenting strategies of peripheral cultures in the $20^{\text {th }}$ and $21^{\text {st }}$ centuries is the one referring to the modernist problem of compensating for the historical delay of peripheral cultures, i.e., their reaching the standard and acceptance of at least the key attributes of dominant cultures. In the $20^{\text {th }}$ century this problem was examined by applying the concept of the 'modernization' of peripheral cultures, which actually referred to the (eternal) transition of peripheral cultures towards modernism (the key attributes, that were once contemporary,

\footnotetext{
29 Marija Bergamo, op. cit., 250.

30 It is interesting to follow the "case" of the Romanian composer George Enescu. Owing to his partial attachment to the French tradition and being fairly well-positioned with the relevant institutions (on the repertoire of French and other Western European ensembles, as well) on one hand, and on the other hand thanks to the agility of the Romanian post-socialist art institutions, he may retroactively take some place in "the national branch" of the traditional canon of musical pieces.

31 See Valentina Radoman, "Politika identiteta, muzika i govor o muzici u doba globalizacije" ["The Politics of Identity, Music and the Speech on Music in the Globalization Period"], manuscript.
} 
of dominant cultures). The application of this concept usually lead to the obsessive insistence on the part of researchers on the accurate determination of the point when a particular stylistic or composing method (or at least its elements only) was applied for the first time in a peripheral culture, which had already been established in some of the central cultures. This information was not only used as proof (to an imaginary judge, while, in fact, most often to the readers of such research studies from that same peripheral culture) of a successfully completed modernization process, but also as an especially important detail relevant for the (also imaginary) competition with other, usually neighbouring peripheral traditions. Due to the logic of such a narrative, Marija Bergamo had to note: 'Ekspresionizam je jedan od retkih umetničkih pravaca koji su na naše tlo došli gotovo bez zakašnjenja.' ['Expressionism is one of the rare artistic styles that came to our land almost without delay.'] or 'Ekspresionistički val je počeo da prodire van Nemačke ubrzo po svom organizovanju u relativno homogeni pokret. U Poljskoj, Češkoj, Bugarskoj prihvaćen je istovremeno kada i kod nas. Preko Austrije i Češke stigao je i na naše tlo. Najpre u Sloveniju, gde se snažno afirmisao u svim granama umetnosti...' ['The expressionist wave started spreading outside Germany soon after it had been organized into a relatively homogenous movement. In Poland, the Czech Republic and Bulgaria, it was accepted at the same time as in our country. Through Austria and the Czech Republic it reached us, as well. First Slovenia, where it established itself strongly in all branches of art...' $]^{32}$

In the $21^{\text {st }}$ century, however, the strategy of national self-representation in musical discourse has indeed been changed. On one hand, owing to the development of information technology, social changes at the global level - the predominance of neoliberal capitalism, as well as to the legitimization of the most varied (all) styles of artistic or post-artistic expression, the onetime problem of catching up with the achievements of former peripheral and central cultures in terms of time now becomes irrelevant. On the other hand, because of this need for attaining 'radical specificity' in a globalized, homogenous world (which, as mentioned, seems no longer to respect the 'central/peripheral' hierarchy), the onetime problem of the 'time gap' is now never hidden or justified, but is, on the contrary, stressed as a special value. As in early musical modernism, while the development of national communities in Europe was in full swing and when Stravinsky, Bartók and other composers from peripheral cultures joined the radical modernist discourse drawing inspiration or specific musical material from ancient, pagan layers of the folklore tradition, now, in the $21^{\text {st }}$

32 Marija Bergamo, op. cit., 23, 24. 
century composers very often again resort to allegedly autochthonous, archaic local folklore traditions (actually, in most cases, to their stereotypical elements, easily recognizable on the global market). This time it is done on behalf of the transnational emancipation of the local expression in a seemingly decentred multicultural vision of the world. The insistence on the alleged autochthony of a particular culture (or some other type of identity) no longer has, as in the $20^{\text {th }}$ century, the purpose of representing the particular (national), the thing that subverts the self-proclaimed 'universal' in art. Quite the opposite. The local is now in the service of the 'universal' which has, however, (plainly) been reached through the economy, not through art. This local is now in the service of representing ideals, as noted by Žižek or Šuvaković or other authors, the illusion of a universal, tolerant multicultural society that does not allow hierarchical, ethnic, racial, gender and other sources of social conflicts (not for the sake of the idealistic protection of ethnic, racial, gender and other entities though, but in order to enable the smooth flow of Capital). ${ }^{33}$

To all the musicology researchers who do not understand this resorting to the 'specific local' expression by contemporary composers in the context of the early $21^{\text {st }}$ century, this local, most often national or subnational overtone in socalled art music will continue to be the occasion for populist odes to 'preserving tradition', 'remembering one's own culture that has to be saved from oblivion', the 'individual', 'specific' and also an occasion for (the still theoretically ungrounded) comparison with the Others. To the researchers who analyze musical works in the context of globalization and multiculturalism, the issue of comparative studies will become more complex than it is now. Apart from the basic questions that ought to be have already been taken into consideration, such as: 1) what is compared in comparative studies in musicology?; 2) what are the criteria for the selection of the examples for comparison?; 3) how, i.e. according to which scientific rules, are the selected examples compared?; 4) what is the reason and aim of comparative research studies?, researchers will yet face a new scientific challenge. That question is primarily tinged with an important political-ideological dimension (which has, as pointed out, notably marked comparative studies from their beginning to this day): how can the problems of comparative research studies in musicology be articulated outside the context of

33 Cf. for instance: Slavoj Žižek, Škakljivi subjekt; Odsutno središte političke ontologije [The Ticklish Subject; The Absent Centre of Political Ontology], Sarajevo, Šahinpašić, 2006; or Miško Šuvaković, 'Ideologija izložbe: o ideologijama Manifeste' ['The Ideology of Exhibition: on the Ideologies of Manifesta'], Platforma SCCA, Zavod za sodobno umetnost, Ljubljana, no. 3, January 2002. 
global capitalism and multicultural ideology? If, in their early stage of development, comparative studies supported or built a discourse of 'national capitalism' in order to challenge it in the course of time (mostly in literary studies), then contemporary comparative studies in all fields of humanistic research should also closely re-examine numerous facets, i.e. both sides constituting the aura of today's global capitalism. The alleged post-politicality of this stage of capitalism makes quite a good starting point for such re-examination.

Translated by Goran Kapetanović

\section{REFERENCES}

Andreis, Josip: 'Stil', Muzička enciklopedija, 3, Zagreb: Jugoslavenski leksikografski zavod, 1971, 458.

Beker, Miroslav, 'Tekst/Intertekst', in: Intertekstualnost \& Intermedijalnost, Zagreb: Zavod za znanost o književnosti, 1988, 11.

Bergamo, Marija, Elementi ekspresionističke orijentacije u srpskoj muzici do 1945. godine, Belgrade: Srpska akademija nauka i umetnosti, 1980.

Dičev, Ivajlo, „Eros identiteta” in: Balkan kao metafora: između globalizacije i fragmentacije, Dušan I. Bjelić, Obrad Savić, eds., Belgrade: Beogradski krug, 2003, 278.

Đurišin, Dioniz, Šta je svetska književnost? (trans. Miroslav Dudok), Sremski Karlovci, Novi Sad: Izdavačka knjižarnica Zorana Stojanovića, 1997, 13.

Elsner, Jaś, 'Style', in: Critical Terms for Art History, ed. Robert. S. Nelson and Richard Shiff, Chicago: University of Chicago Press, 2003.

Eror, Gvozden, Književne studije i domen komparatistike [Literary Studies and the Domain of Comparative Studies], Beograd, Pančevo: Institut za književnost i umetnost, Mali Nemo, 2007, 9, 15.

Flaker, Aleksandar, Stilske formacije, Zagreb: Sveučilišna naklada Liber, 1986 (1976), 64.

Giljen, Klaudio, Književnost kao sistem: ogledi i teorija književne istorije (trans. Tihomir Vučković), Beograd: Nolit. 1982, 43.

Gossman, Lionel: Between History and Literature, Cambridge: Harvard University Press, 1990, 286.

Hanslick, Eduard, Vom musikalisch-Schönen; Ein Beitrag zur Revision der Ästhetik der Tonkunst, Leipzig: Breitkopf\&Hartel, 1910.

Harsanyi, D., N. Harsanyi, 'The Discreet Charm of the Little Sister: France and Romania', in: East European Quarterly, Summer, 1994, No. 2, 16.

Herzfeld, Michael, „Uvod ”, in: Balkan kao metafora: između globalizacije i fragmentacije, Dušan I. Bjelić, Obrad Savić, eds., Belgrade: Beogradski krug, 2003, 13.

Konstantinović, Zoran, 'Čemu komparatistika? O nekim nedoumicama u razvojnim tokovima naše kulture', in: Polazišta; Izbor iz radova Zorana Konstantinovića, Novi Sad: Prometej 2000, 33.

Konstantinović, Zoran, Komparativno viđenje srpske književnosti, Novi Sad: Svetovi, 1993, 6, 47. 
Radoman, Valentina, "Politika identiteta, muzika i govor o muzici u doba globalizacije" ["The Politics of Identity, Music and the Speech on Music in the Globalization Period"], manuscript.

Taruskin, Richard, 'Nationalism', The Revised Grove Dictionary of Music and Musicians, ed. Stanley Sadie and John Tyrrell, XVII, Basingstoke: McMillan, 2001, 687-706.

Said, Edward, Culture and Imperialism, London: Chatto and Windus, 1993.

Stojković, Branimir, Identitet i komunikacija [Identity and Communication], Belgrade: Čigoja štampa/Fakultet političkih nauka, 2002, 16.

Šuvaković, Miško, 'Ideologija izložbe: o ideologijama Manifeste' ['The Ideology of Exhibition: on the Ideologies of Manifesta'], Platforma SCCA, Zavod za sodobno umetnost, Ljubljana, no. 3, January 2002.

Žižek, Slavoj, Škakljivi subjekt; Odsutno središte političke ontologije [The Ticklish Subject; The Absent Centre of Political Ontology], Sarajevo: Šahinpašić, 2006. 